\title{
プロトプラストを用いた花粉発生の分子形態学
}

田中一朗

横浜市立大学大学院生命ナハシステム科学研究科き236-0027 神奈川県横浜市金沢区瀬戸22-2

要旨: 被子植物の花粉発生は, 栄養成長から生殖成長への転換によって形成された花芽の葯内で始まり, 受粉後 2 個の精細胞が胚のう中の卵細胞ならびに2 個の極核をもつ中央細胞と重複受精することによって終わる. この間, 花粉母細胞の減数分裂による半数性 $(n)$ 細胞 (小胞子) の形成, 小胞子の不等 (細胞) 分裂による雄原細胞と栄養 細胞の分化，花粉管の伸長と一連の劇的な細胞学的変化がみられる. ところが，花粉母細胞は厚いカロースから 成る細胞壁を，そして小胞子や花粉は不溶性のスポロポレニンから成る固い外壁をもつため，通常の細胞学的手法 では詳細な内部構造を観察することは困難であった。従って, 内部構造に関する研究は電子顕微鏡法を中心とし て切片を試料にするのが一般的であった。 しかしながら, 切片試料の作製においても, 花粉発生過程にある細胞は 他の細胞に比べて難しく, また切片像からの三次元構築もまだ容易ではなかった。 そこで, 蛍光抗体法などの適用 を可能にするために，体細胞の場合と同様に，プロトプラストの単離を試みた。 その結果，テッポウユリにおいては， 特有の外壁をもつ花粉からのプロトプラスト (花粉プロトプラスト) を初めとして, 花粉発生過程の多くの時期にある細 胞からプロトプラストが得られるようになった. ほぼ同時進行の生化学的研究で見出した特異的タンパク質を抗原に, 特異的抗体を作製し, 単離したプロトプラストに蛍光抗体法を適用したところ, 従来予想されていた現象や機構のい くつかを初めて分子の動態として可視化することができた.

\section{Molecular morphological studies on pollen development using protoplasts}

\section{Ichiro Tanaka}

Graduate School of Nanobioscience, Yokohama City University,

Seto 22-2, kanazawa-ku, Yokohama, Kanagawa 236-0027 Japan

Author for correspondence: Ichiro Tanaka, itanaka@yokohama-cu.ac.jp

Summary: Pollen development in angiosperms starts in anthers within buds formed by conversion from vegetative growth to reproductive growth, and results in double fertilization at which one sperm cell fuses to an egg cell and the other sperm cell fuses to a central cell including two polar nuclei. During this process, there are drastic cellular changes such as production of haploid cells by meiosis in pollen mother cells, differentiation of the generative cell and the vegetative cell by an unequal (asymmetric) cell division in microspores and growth of pollen tubes. However, it is generally difficult to observe the inner structure under an ordinary light microscope because the pollen mother cells possess callosic cell wall, and microspores and pollen grains further have a thick exine consisting of insoluble sporopollenin. Therefore, the observation has usually been conducted on sectioned samples as in the case with electron microscopy. In order to make the observation easy, we tried to isolate protoplasts free from cell wall and exine in Lilium longiflorum. As a result, pollen mother cell protoplasts, microspore protoplasts, pollen protoplasts and generative cell protoplasts could be obtained in large quantities. On the other hand, biochemical research suggested several specific proteins appeared during pollen development. Using specific antibodies raised against the specific antigens, immunofluorescence studies on isolated protoplasts first revealed dynamics of the specific proteins during pollen development.

Key words: chromatin, centromere, histone, Lilium longiflorum, male gamete, meiosis

\section{花粉発生}

花粉は，種子植物の雄性配偶体であり，有性生殖 における中心的な存在である。すすなわち，花粉は，雌 しべの柱頭に受粉すると，花粉管を伸長し，含有する 雄性配偶子を胚のう中の卵細胞まで運搬する。一方で, 花粉を植物細胞として見た場合, 最も大きな特徴は不 溶性のスポロポレニンから成る厚い外壁 (花粉壁)をも
つことである(図1)。この外壁の彫紋模様は種特異的 であり，生物多様性の最たるものの一つと言える，その ため, 花粉形態学はかつて植物の一つの大きな分野 であった。一方で，生きた花粉の構造や機能を分子細 胞生物学的に解析寸る際には, この外壁の存在は大 きな障害であった。 


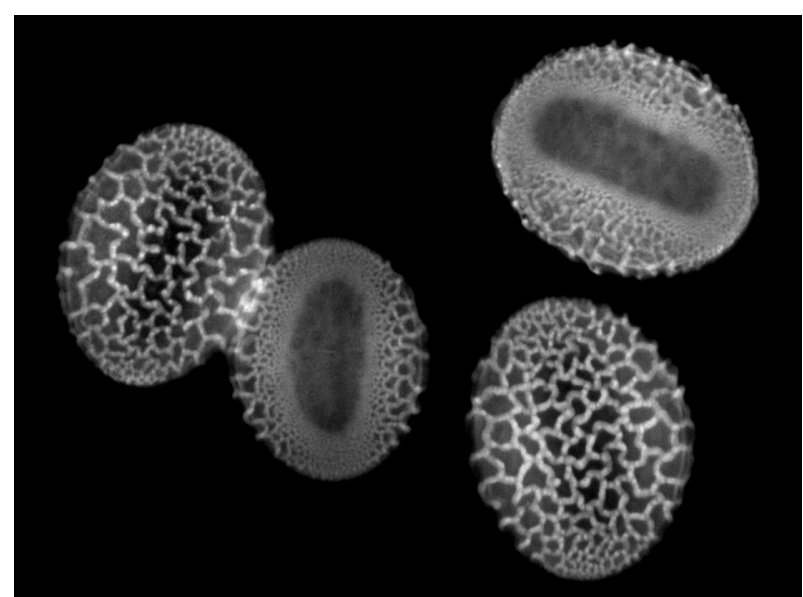

図 1 テッポウユリの花粉外壁. 発芽溝側からみたものと逆側 からみたものをそれぞれ2個ずつ示す。

葯内の花粉発生では，まず花粉母細胞の減数分裂 によって花粉四分子 (小胞子)を生じるが，花粉母細胞 の母細胞壁や減数第一分裂ならびに減数第二分裂後 の隔壁の主成分はいずれも通常のセルロース $(\beta-1,4-$ グルカン) ではなくカロース $(\beta-1,3-$ グルカン $)$ である.

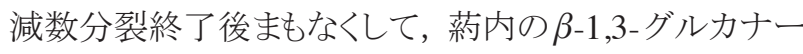
ゼによって四分子は解離し，4個の小胞子を遊離する が，解離前にそれぞれの小胞子には外壁がすでに作 られ始めている，その際，外壁の形成は一様ではなく， 将来の花粉管が出る部位, 寸なわち発芽孔 (溝)を空 けておく. 小胞子が遊離後, スポロポレニンのさらなる 沈着による外壁の急激な発達が起こり，表面上の花粉 の形態形成は完了寸る (図1).

ところが，生殖細胞としての花粉の重要な機能の獲 得は, その後の小胞子発生で起こる(図2). 寸なわち, 小胞子分裂による雄原細胞と栄養細胞の分化である.

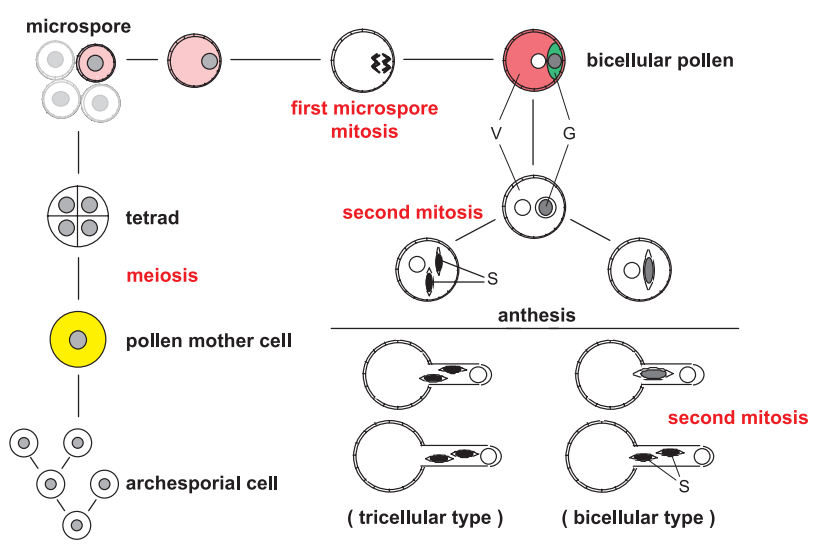

図 2 被子植物の花粉発生過程. G: 雄原細胞, V: 栄養細胞, $\mathrm{S}$ : 精細胞.
被子植物の場合, 雄原細胞は, その後花粉管中ある いは花粉内で 2 個の精細胞一と分裂し，被子植物特有 の重複受精に直接関与寸る. 一方の栄養細胞は，受 粉後発芽し，花粉管を伸長することによって，雄性配 偶子細胞を胚のうまで運搬する，機能が大きく異なるこ の両細胞の分化を導く小胞子分裂は，大きな細胞と小 さな細胞を生じる典型的な不等 (細胞) 分裂である。 そ のために，分裂前の小胞子では，核の細胞の一端へ の移動がみられるとともに，不均斉な核分裂 (二つの紡 錘体極の状況が異なる) 後の細胞質分裂では，細胞の 外側に位置する核を取り囲むわん曲した隔壁が作られる. この隔壁の主成分もまたカロースである．結果的に，よ り外側の核を含む小さな細胞が雄原細胞に, 内側の核 を含む大きな細胞が栄養細胞に分化することになるが， さらに雄原細胞は栄養細胞の細胞質中に遊離した，い わゆる「入れ子」の細胞となることが大きな特徴である(図 2).しかしながら, 外壁の存在のため, 小胞子や花粉 発生過程の詳細な観察は電子顕微鏡を中心として切 片を試料に用いるのが通常であった。今では，この雄 原細胞と栄養細胞では，受精と花粉管伸長に向けて， それぞれで数々の特異的な遺伝子発現が起こることが 明らかになっている (Tanaka 2006)。

\section{テッポウユリのプロトプラスト}

花粉発生の研究において，テッポウユリは，古くから 最もよく使われてきた実験材料の一つである.ゲノムの 巨大なテッポウユリは，細胞や核が大きく，形態観察 に都合がよい，さらに，花粉発生過程では，細胞数が 比較的多い上，蕾の長さと発生ステージの間にきれい な相関がみられ，かつ細胞間の同調性が極めて高い ので, 生化学的研究にも優れている. また, 貯蔵球根 を温室栽培することによって，ほぼ一年中生の実験材 料を得ることができる，そして，何よりも，それらからプ ロトプラストを得ることができることである（Tanaka 1996）.

一般の体細胞 (葉など)からプロトプラストを得るには, 細胞間物質のペクチンを溶解するペクチナーゼと細胞 壁のセルロースを溶解するセルラーゼが必要である. それに対して, 減数分裂中の花粉母細胞や終了直後 の四分子からプロトプラストを得るには，カロースを溶解 する必要がある. 古くは, カタツムリの消化酵素やセル ラーゼの粗標本が使われたりしていたが，今では高い

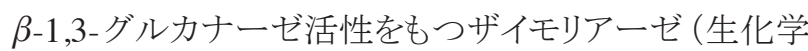


工業)の添加で十分である (Tanaka 1991).

一方，小胞子や花粉からのプロトプラストは，外壁の 成分であるスポロポレニンを溶解できる酵素がこの世に 存在しないために，不可能さされていた。ところが，固 定した試料を酸中で熱すると中身が外壁からきれいに飛 び出すことをヒントに，通常の酵素処理 (ペクチナーゼ 処理とセルラーゼ処理) を低張液中で試みたところ，以 外にも容易にプロトプラスト化できることがわかった（Tanaka et al. 1987)。ただし，この手法の適用は発芽孔 (溝)の 大きな種に限定され，今でもテッポウユリを超えるものは ない. 酵素処理後遊離したプロトプラストは，パーコー ルの密度勾配遠心によって不溶性の外壁を除去すると， 均一な花粉プロトプラスト集団として単離できる (図3).

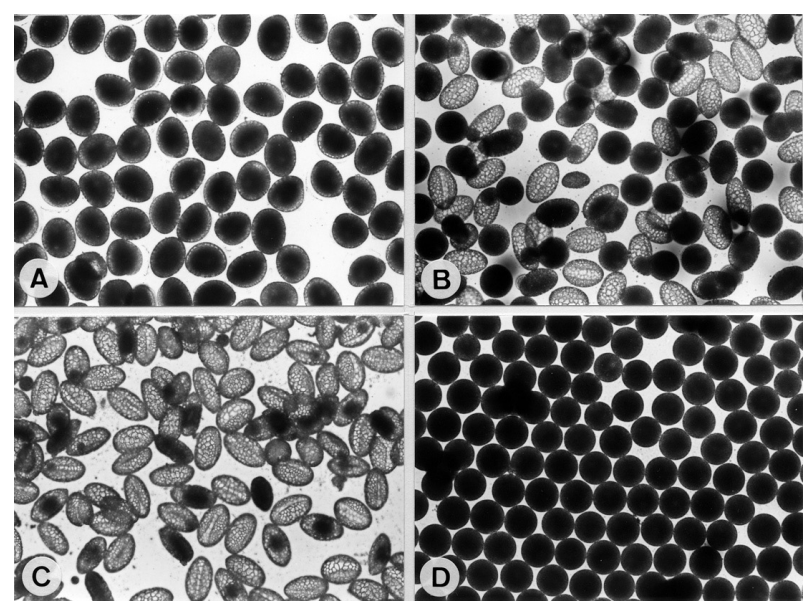

図 3 テッポウユリ花粉プロトプラストの単離過程. A: 酵素処 理前の花粉， B: 酵素処理中の花粉， C: パーコール密度勾 配遠心分離後の花粉外壁，D: パーコール密度勾配遠心分 離後の花粉プロトプラスト.

これらのプロトプラストは，すぐ花粉，特に内部に「入 れ子」で存在する雄原細胞の形態観察に大きな威力を 発揮した (Tanaka 1993) とともに，ほぼ同時に進行中で あったテッポウユリを用いた生化学的研究と併せて，い くつかの新知見をもたらした。

\section{減数分裂に特異的な動原体の動態解析}

有性生殖に先立ち染色体数半減に重要な減数分裂 は，動植物間で違いのみられる点は多いものの，共 通の基本的な染色体の挙動の基に成り立っている. そ れは，相同染色体の対合と交叉，第一分裂における (姉妹) 染色分体の不分離と第二分裂における (姉妹) 染色分体の分離である. こうした染色体の動態を可視
化する上で，染色体の構造・機能ドメインを標識でき ることは最も有効な手段である。哺乳動物では，ヒ卜の 自己免疫病患者の血清が体細胞分裂時や減数分裂時 の動原体を特異的に認識できていたが，植物細胞に は適用できなかった。今では，ヒ下の動原体タンパク質 CENP-A (ヒストン H3 変種) などの相同タンパク質が植 物でも見出され，その抗体を用いてタバコなどの動原 体を可視化できるようになった (Nagaki et al. 2009) が, 減数分裂時の動原体の詳細な動態は明らかにされてい ない。一方，テッポウユリを含むユリ科植物の一部では， 花粉母細胞の減数分裂に先立ち, 体細胞には存在し ない特異的なヒストン $\mathrm{H} 1$ 様変種が出現することが古くか ら知られていた (Sheridan and Stern 1967)。このたんぱ く質を抗原とした抗血清の中に，花粉母細胞の動原体 を認識するものが見出され，共焦点レーザー顕微鏡の 使用により，減数分裂に特異的な動原体の動態，す なわち第一分裂前期の合糸期・太糸期・複糸期にお ける相同動原体の会合・融合・解離，後期における 姉妹動原体の不分離，第二分裂後期における姉妹動 原体の分離を光学顕微鏡レベルで初めて連続的に可 視化することができた (Suzuki et al. 1997).さらに，第 一分裂中期における微小管との多重染色により，動原 体微小管が一方の極とつながり，相同染色体の分離方 向が決まると，第二分裂に備えて，姉妹動原体がそれ ぞれ識別できるように構造変化することもわかった（図 4, Suzuki and Tanaka 1999)。これらの知見は，花粉母細 胞プロトプラストへの抗体染色をスタートとして得られた ものであるが，その後は固定後の酵素処理試料でも十 分抗体染色できるようになった。

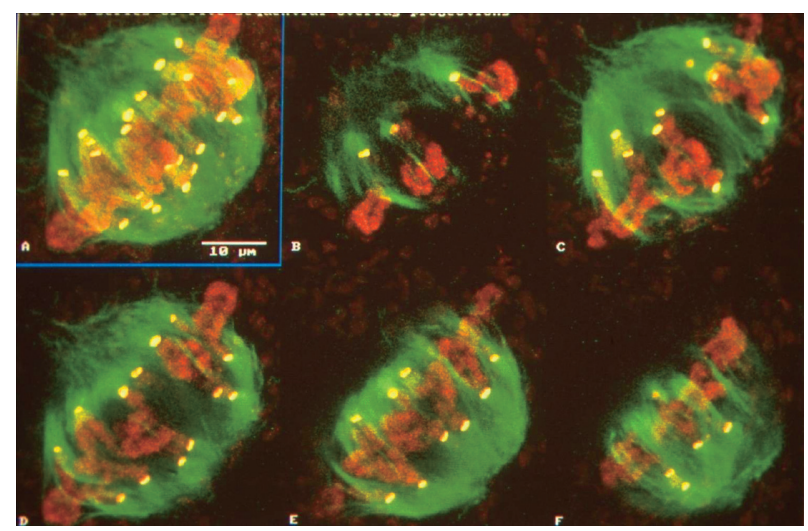

図4 三重染色したテッポウユリ花粉母細胞プロトプラストの共 焦点レーザー顕微鏡像. 赤: 染色体, 緑: 微小管, 黄: 動 原体，a: 合体像，b-f: 切片像. 
テッポウユリ花粉母細胞の動原体を認識する抗血清は, 同じ減数分裂を行う胚のう母細胞の動原体も同様に認 識するが，同じテッポウユリでも，体細胞分裂時の動 原体は認識しない。このことから，染色体の重要なドメ インである動原体には，動物でも植物でも，特殊なヒス トン変種が局在していると言えるが，さらに減数分裂時 には体細胞分裂時とは異なる分子が機能し，減数分裂 に特異的な動原体の挙動を制御している可能性が示唆 される.

\section{雄性配偶子特異的ヒストン変種の動態}

テッポウユリの花粉プロトプラストは，何よりも，内部 に「入れ子」で存在する雄原細胞の単離に有用であった. それまで，花粉を直接壊すことによって雄原細胞を単 離しようとする試夕は数多くなされていたが，強固な外 壁をもつ花粉の破壊は同時に雄原細胞の破壊を招いた。 それに対して，花粉プロトプラストを温和に壊した場合 は，intactな雄原細胞をそのまま大量に得ることができ る (Tanaka 1988)，雄原細胞は，精細胞の前駆細胞で あるとはいえ，雄性配偶子的細胞である．それは，色 素体などのオルガネラを含まず，その核は高度に凝縮 している.

そこで，動物の精子核同様高度に凝縮した雄原核ク

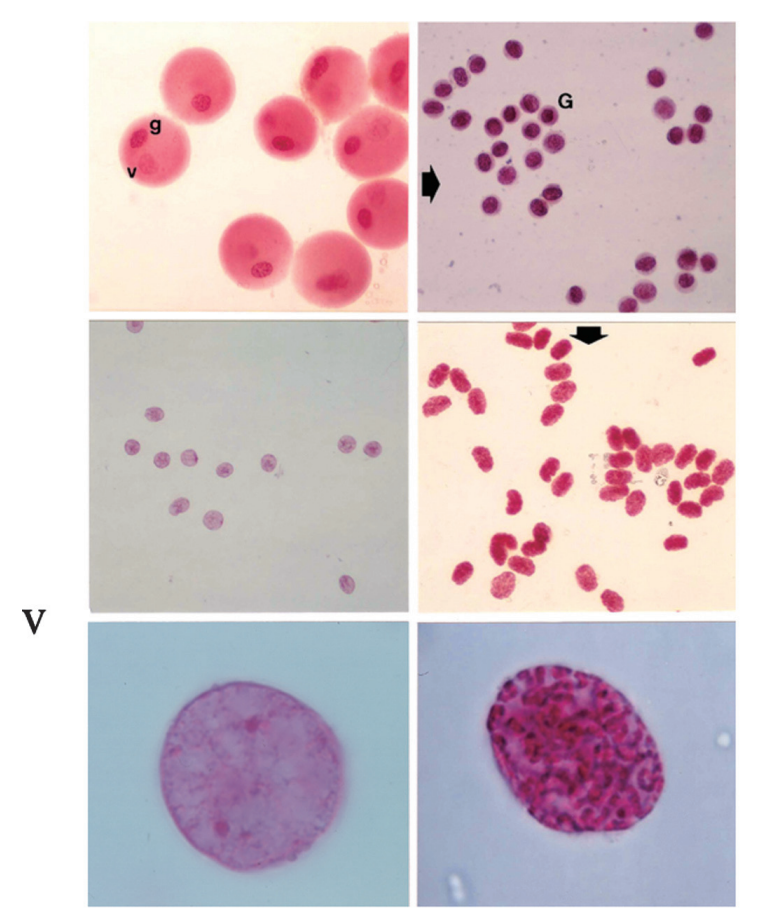

図 5 花粉プロトプラストからの雄原核の単離. $\mathrm{g}$ : 雄原核, v: 栄養核, G: 雄原細胞.

g
ロマチンに着目し，そのヒストン組成の解析を試みた。 それまで，花粉を壊して雄原核と栄養核を分別して単 離しようとする試みも盛んに行われていたが，いずれも 不完全に終わっていたので，テッポウユリの雄原細胞 単離系を利用した (図5)。

この方法では，破壊した花粉プロトプラストからパー コールの密度勾配遠心によって $100 \%$ 純粋な雄原細胞 集団を得ることができるので，それらをさらに破壊するこ とによって，栄養核フリーの雄原核試料が得られる。乙 こで，その雄原核から塩基性タンパク質 (ヒストン)を抽 出し，二次元電気泳動法によって，一般の体細胞核 である葉の核などとの詳細な比較が初めて可能になっ た (Ueda and Tanaka 1994)。この比較によって雄原核 特異的と期待された三つのタンパク質スポッ卜は，まず それぞれの特異的抗体を作製することによって，花粉 特異的であることはウエスタン法で実証された。しかし ながら，さらにそれらが真に雄原核特異的であることは， 花粉プロトプラストを用いた形態学的証明が必須であつ た(図6).

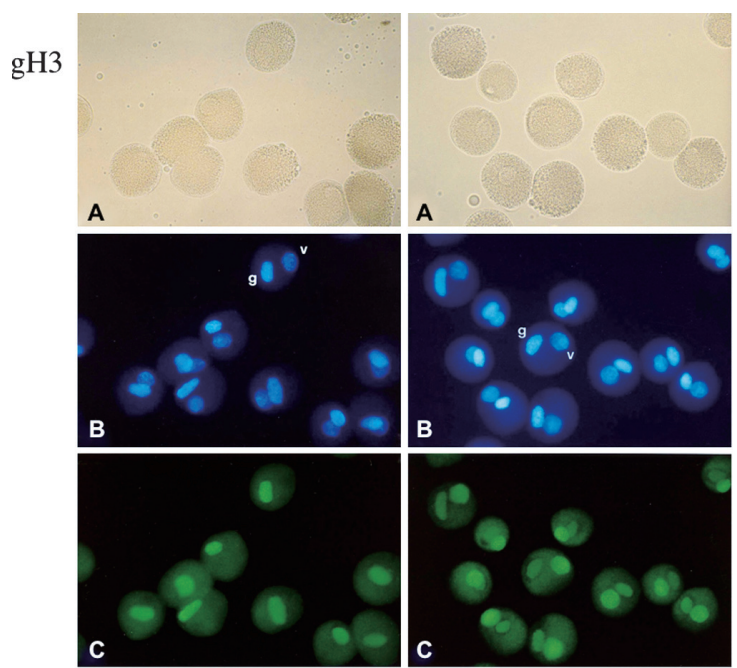
$\mathrm{H} 2 \mathrm{~B}$

図6 花粉プロトプラストにおける雄原核特異的ヒストン $(\mathrm{gH} 3)$ の検出. A: 明視野像, B: DAPI蛍光像, C: 蛍光抗体像, H2B は対照. g: 雄原核, v: 栄養核。

単離した花粉プロトプラスト(図6A)をDAPI染色する と，それぞれの花粉内の2 個の核，雄原核と栄養核は 明瞭に観察される。その際，雄原核は楕円形で蛍光 強度が強いのに対し，一方の栄養核はほぼ円形で染 色性は弱い(図6B)。ところが，抗体染色では，対照 とした抗ヒストンH2B抗体が両核を，しかも円形の栄養 核をより強く染色するのに対し，雄原核特異的と想定さ 
れたヒストン変種の一つに対する抗 $\mathrm{gH} 3$ 抗体では, 雄 原核の夕が特異的に染色される (図 6C)。このようにし て, 雄原核特異的ヒストン変種 $(\mathrm{gH} 2 \mathrm{~A}, \mathrm{gH} 2 \mathrm{~B}, \mathrm{gH} 3)$ の 存在は花粉プロトプラストを用いた形態学的研究によっ て最終的に証明された (Ueda and Tanaka 1995a)。この 特異的ヒストン変種は雄原核の分裂によって生じる精核 にも存在する (Ueda and Tanaka 1995b) ので, 正確に は雄性配偶子核特異的であるが，この証明にも，後述 の花粉プロトプラスト培養系が有効に使用された。この 新知見, 寸なわち雄性配偶子特異的ヒストンの存在は, その後別のグループにより遺伝子発現の面からもタン パク質の面からも支持されている (Xu et al. 1999, Okada et al. 2006). いずれにしても，その機能は想像の域を 出ないが，雄性配偶子特異的ヒストンの存在は動植物 共通の現象として興味深い. 現在, 受粉・受精過程 における雄性配偶子特異的ヒストンの消長を調査中で あるが，少なくても受精直後にはまだ受精卵中に存在 している.

\section{花粉管伸長機構}

花粉の最大の生理機能は, 発芽し, 花粉管を伸長 することである.この発芽と花粉管伸長に関しては，す でに多くの研究がなされ, Caとアクチン繊維(F-アクチン, $\mathrm{AF}$ と略)の重要性が形態的に示されている. 寸なわち, 花粉が吸水し, 発芽過程に入ると, 発芽孔付近に $\mathrm{Ca}$ の局在がみられる，また，伸長中の花粉管では，管先 端部にCaが集中し, 先端から基部に向かって $\mathrm{Ca} の$ 勾 配がつくられる. 花粉管内のこの Ca の濃度勾配が乱さ れると，花粉管の伸長が阻害されたり，逆にin vitroで の培地にCaを添加すると花粉管伸長が促進されること から, 花粉管伸長におけるCaの影響は大である. 一方, $\mathrm{AF}$ 発芽過程においてはCa と似たような動向を示し, 発芽孔に集中するが，花粉管中では䋊維状の $\mathrm{AF}$ が軸 方向に配向するようになる。この䋊維状の $\mathrm{AF}$ がサイト カラシン処理などで壊されると, やはり花粉管伸長が阻 害されることから，AFも花粉管伸長の重要な因子であ ることがわかる．しかしながら，花粉管中での形態観察 が比較的容易に行えるのに対し，未発芽の花粉内の 観察は外壁の存在のために容易ではなかった。 そこで, テッポウユリ花粉プロトプラストの培養系を利用した(図 7).

花粉プロトプラストは，通常の体細胞プロトプラストと 同様，培養液中で細胞壁を再生するが，さらに培養を
続けると球形から棈円形に変化し, やがて花粉管を伸 長する.もちろん, この過程で外壁の再生はないが, 雄原細胞の精細胞への分裂は起こる.この花粉プロト プラスト培養系でAFを観察すると, 当初は網目状の微 細な $\mathrm{AF}$ が徐々に繊維状に構築され，やがて細胞が球 形から棈円形に変形するころになると, $\mathrm{AF}$ は細胞の短 軸方向に配向し，発芽すると花粉管中に流入するのが わかる(図 8 ; Tanaka and Wakabayashi 1992).

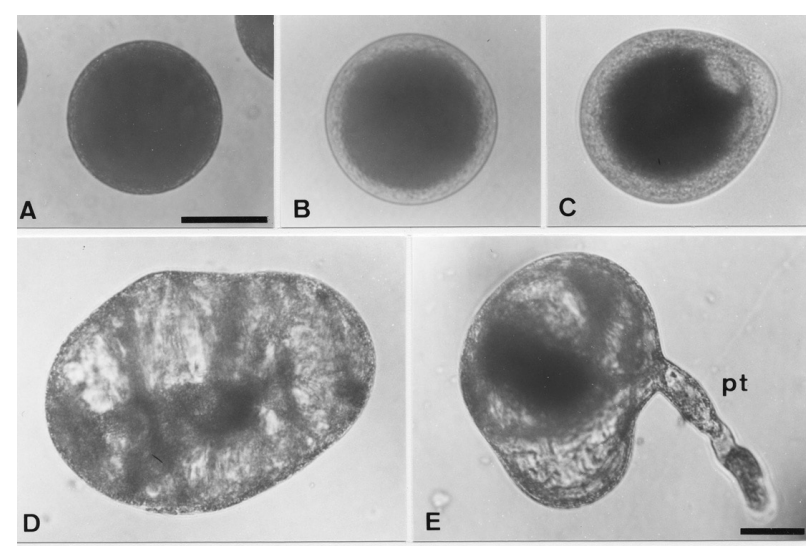

図 7 テッポウユリ花粉プロトプラストの培養. A: 0 日目，B: 4 日目，C: 5 日目，D: 7 日目， E: 8 日目，pt: 花粉管，バー: $50 \mu \mathrm{m}$.
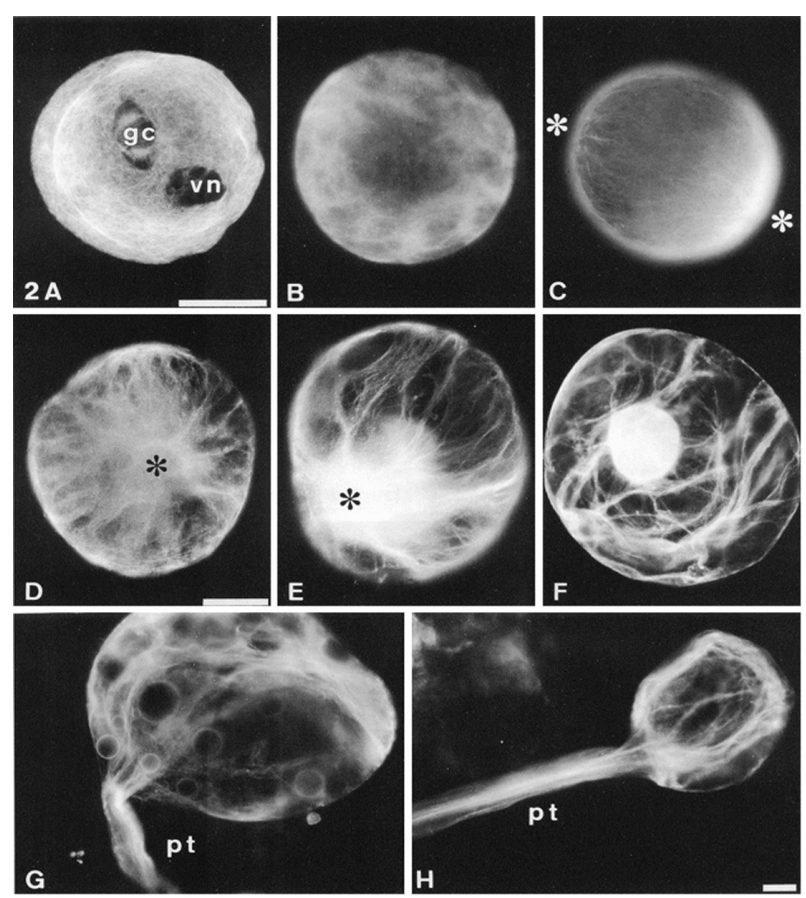

図 8 テッポウユリ花粉プロトプラストの培養過程における $\mathrm{AF} の$ 変化. A: 0 日目, B: 3 日目, C: 4 日目, D: 5 日目, E: 6 日目, F-H: 8 日目, gc: 雄原細胞, vn: 栄養核, pt: 花粉管, 星印: $\mathrm{AF}$ の集中部，バー: $50 \mu \mathrm{m}$. 
花粉プロトプラスト培養系での AFの動態は, intact な花粉のものとは異なる可能性もあるが，それまで十分 見えなかったものが見えたことは一見の価值があると思 われる。一方，図7の結果は，花粉の発芽が外壁が なくても起こることを示しており，外壁が発芽孔を規定し ているのではなく，発芽の部位を決める機構が別にあ ることを示唆している. 花粉プロトプラストは，一般の体 細胞プロトプラストと同様細胞融合が可能で， 2 3 個 の融合体が容易に得られるが，その多くがやはり 1 本 の花粉管を伸長することからも，発芽部位の決定が再セッ トされることが推察される.

花粉管伸長のためには，他にも多くの遺伝子発現 が必須であり，細胞壁 (花粉管壁) の合成や分解に 関わる分子の存在が知られている (Taylor and Hepler 1997）。花粉症の原因物質であるアレルゲンもその一 つである，花粉管は先端成長であるために，花粉管 壁の成分は一般にゴルジ体由来の小胞により先端部 分に運ばれる. テッポウユリでは，花粉特異的なLEA 様タンパク質 (LP28) が見出されている (Mogami et al. 2002) が, こうしたタンパク質の動態や機能をみるために, GFPなどのレポーター遺伝子とともに，花粉プロトプラ ストに高率で遺伝子導入する実験系も整備され利用さ れている (図9; Miyoshi et al. 1995).

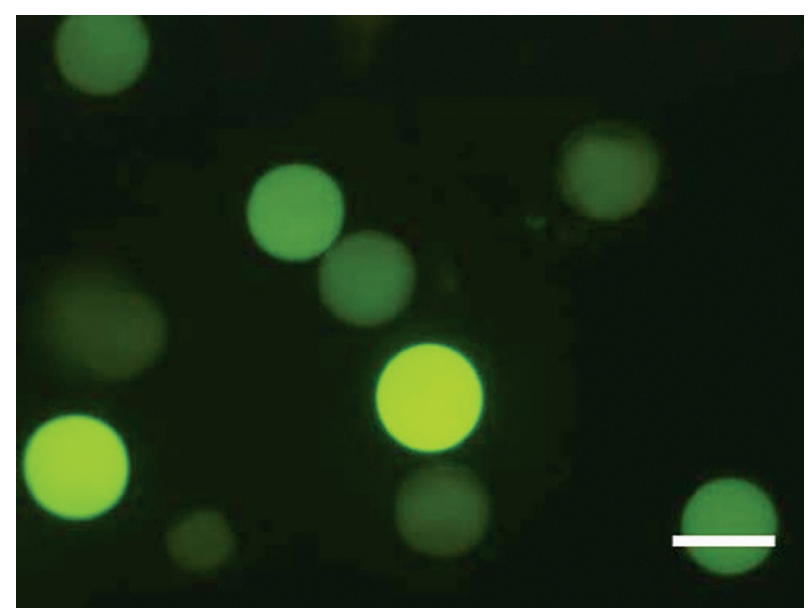

図9 花粉プロトプラストへのレポーター遺伝子 $(G F P)$ の導入 と発現. バー: $100 \mu \mathrm{m}$.

\section{おわりに}

本稿は, 平成 22 年度の日本植物形態学会「学会賞」 の受賞講演をまとめたものである.

卒業研究を行うために, 名古屋大学理学部生物学 教室の伊藤道夫 $(\mathrm{M})$ 研究室に入り, テッポウユリの染

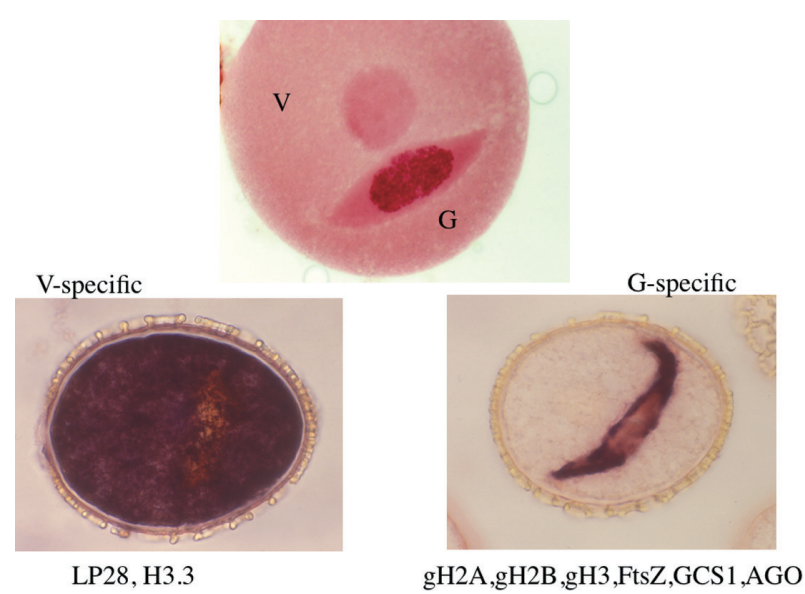

図 10 テッポウユリの栄養細胞 $(\mathrm{V})$ と雄原細胞 $(\mathrm{G})$ で特異的 に発現, 翻訳されるタンパク質. H3.3: Sano and Tanaka (2007), FtsZ: Mori and Tanaka (2000), GCS1: Mori et al. (2006).

色体に感動して以来 40 年近く，一貫してテッポウユリを 研究材料としてきた. その間，シロイヌナズナを中心と した分子遺伝学が大きく進展するなか, 独自の花粉細 胞形態学を展開できたのは，ここに紹介したプロトプラ ストに負うところが大であり，私にとってはプロトプラスト 様さまである. 一方で, 細胞レベルの研究は進展が遅 く，亀のような歩みであったが，プロトプラストをスタート に何とか分子レベルまで到達することができた（図 10）。 しかしながら，花粉発生においては，減数分裂の誘導 機構，小胞子の不等分裂機構，花粉の発芽機構とま だまだ未解明の重要な課題が多く残されているのも事 実である.

この間，年間ほぼ3,000 球のテッポウユリ球根を温室 栽培してきたので，10万個以上の球根を使用したこと になるが，常時生理活性の高いプロトプラストを得るた めには今後も欠かすことができない.

最後に, この一連の研究は科学研究費補助金を基 に行われており，またこの間研究に携わった多くの横 浜市立大学植物細胞遺伝学研究室の卒業生に深謝す る.

\section{引用文献}

Miyoshi, H., Usami, T., and Tanaka, I. (1995) High level of GUS gene expression driven by pollen-specific promoters in electroporated lily pollen protoplasts. Sex Plant Reprod 8: 205-209.

Mogami, N., Shiota, H., and Tanaka, I. (2002) The identification 
of a pollen-specific LEA-like protein in Lilium longiflorum. Plant Cell Environ 25: 653-663.

Mori, T., and Tanaka, I. (2000) Isolation of the ftsZ gene from plastid-deficient generative cells of Lilium longiflorum. Protoplasma 214: 57-64.

Mori, T., Kuroiwa, H., Higashiyama, T., and Kuroiwa, T. (2006) Generative cell specific 1 is essential for angiosperm fertilization. Nature Cell Biol 8: 64-71.

Nagaki, K., Kashihara, K., and Murata, M. (2009) A centromeric DNA sequence colocalized with a centromere-specific histone H3 in tobacco. Chromosoma 118: 249-257.

Okada, T., Singh, M. B., and Bhalla, P. L. (2006) Histone H3 variants in male gametic cells of lily and $\mathrm{H} 3$ methylation in mature pollen. Plant Mol Biol 62: 503-512.

Sano, Y., and Tanaka, I. (2007) Detection of differentially expressed variant histone H3.3 in the vegetative nucleus of lily pollen. Sex Plant Reprod 20: 27-33.

Sheridan, W. F., and Stern, H. (1967) Histone of meiosis. Exp Cell Res 45: 323-335.

Suzuki, T., and Tanaka, I. (1999) Attachment of kinetochores to spindle microtubules during meiosis I of Lilium microsporocytes. Chromosome Res 7: 121-129.

Suzuki, T., Ide, N., and Tanaka, I. (1997) Immunocytochemical visualization of the centromeres during male and female meiosis in Lilium longiflorum. Chromosoma 106: 435-445.

Tanaka, I. (1988) Isolation of generative cells and their protoplasts from pollen of Lilium longiflorum. Protoplasma 142: 68-73.

Tanaka, I. (1991) Microtubule-determined plastid distribution during microsporogenesis in Lilium longiflorum. J Cell Sci 99: 21-31.

Tanaka, I. (1993) Development of male gametes in flowering plants. J Plant Res 106: 55-63.

Tanaka, I. (1996) Haploid protoplasts: pollen protoplasts. In Jain SM, Sopory SK and Veilleux RE eds., In vitro haploid production in higher plants. Vol.2. Kluwer Academic Publishers, the Netherlands, pp.287-307.

Tanaka, I. (2006) Differentiation of generative and vegetative cells by unequal cell division. Plant Morphol 18: 13-18.

Tanaka, I., and Wakabayashi, T. (1992) Organization of the actin and microtubule cytoskeleton preceding pollen germination: An analysis using cultured pollen protoplasts of Lilium longiflorum. Planta 186: 473-482.

Tanaka, I., Kitazume, C., and Ito, M. (1987) The isolation and culture of lily pollen protoplasts. Plant Sci 50: 205-211.

Taylor, L. P., and Hepler, P. K. (1997) Pollen germination and tube growth. Annu Rev Plant Physiol Plant Mol Biol 48: 461-491.

Ueda, K., and Tanaka, I. (1994) The basic proteins of male gametic nuclei isolated from pollen grains of Lilium longiflorum. Planta 192: 446-452.

Ueda, K., and Tanaka, I. (1995a) Male gametic nucleus-specific $\mathrm{H} 2 \mathrm{~B}$ and $\mathrm{H} 3$ histones, designated $\mathrm{gH} 2 \mathrm{~B}$ and $\mathrm{gH} 3$, in Lilium longiflorum. Planta 197: 289-295.

Ueda, K., and Tanaka, I. (1995b) The appearance of male gamete-specific histones $\mathrm{gH} 2 \mathrm{~B}$ and $\mathrm{gH} 3$ during pollen development in Lilium longiflorum. Dev Biol 169: 210-217.
Xu, H., Swoboda, I., Bhalla, P. L., and Singh, M. B. (1999) Male gametic cell-specific expression of $\mathrm{H} 2 \mathrm{~A}$ and $\mathrm{H} 3$ histone genes. Plant Mol Biol 39: 607-614. 